\title{
Whole Language Approach Implementation as a Child Language Learning Model Development
}

\author{
Nanda Saputra ${ }^{1}$, Wiputra Cendana ${ }^{2}$, Irnie Victorynie ${ }^{3}$, Khaidir $^{4}$ \\ ${ }^{1}$ STIT Al-Hilal Sigli, Indonesia \\ 2Universitas Pelita Harapan, Indonesia \\ 3Universitas Islam 45 Bekasi, Indonesia \\ 4IAI Al-'Aziziyah, Indonesia \\ Email: nandasaputra680@gmail.com
}

\begin{abstract}
:
This research was conducted to implement a holistic language approach (whole language approach) as a development model for students' language learning at SDN (Public School) 2 Sigli. This study uses a classroom action research method by providing action in each cycle starting from planning, acting, observing, and reflecting. This research was conducted at the Sigli 2 Public Elementary School. The subjects of this study consisted of 10 students consisting of 6 boys and 4 girls. The results of observations were processed through data analysis techniques with descriptive statistics, namely finding the percentage and average value of the improvement in Indonesian language skills obtained through observation, interviews and discussions, and document review. The results showed that the implementation of the whole language approach which includes immertion, demonstration, expectation, responsibility, employment, approximation, and feedback can improve students' reading ability. Based on the results of observations in the pre-cycle, the percentage of pre-cycle reading ability was still $30.25 \%$. In the first cycle, after the action was carried out for 7 meetings, the percentage increased to $85.50 \%$. Based on these data shows an increase in the percentage of reading ability from the results of pre-cycle observations by $55.25 \%$. The implication of this research is that the whole language approach is expected to be used as the development of a language learning model at SDN 2 Sigli, because it is natural and fun and is the same age as the stages of student development.
\end{abstract}

Keywords:

whole language approach; language skills; students

\section{Introduction}

In the era of globalization, competition and competition are increasingly open, education as a transformation of human resource development must be oriented and emphasized so that the implementation of meaningful education, because meaningful education will be able to make a positive contribution to life, and can meet the demands of life in the future. Intense competition resulted in the demand for quality education is a must so that the approach in education that has been going on is no longer relevant.

Education today must provide opportunities for every individual to be able to learn throughout life to develop their knowledge, attitudes and skills. For this reason, education must rely on the four pillars of education from UNESCO, namely, (1) Language to know, namely learning to know, (2) Language to do, namely learning to do, (3) Language to be, namely learning to make something, (4) Language to live together, namely learning to live together (Dellors, 1996 in Dantes, 2014: 38, and Marhaeni, 2012: 116). 


\section{Linglit Journal: Scientific Journal of Linguistics and Literature \\ ISSN: 2774-4523 (Online), 2774-4515 (Print)}

Vol. 2, No. 4, December 2021, Page: 161-172

Email: linglitjournal@gmail.com

Based on the explanation above, in the learning process the teacher must dare to make various breakthroughs and learning innovations, so that learning no longer places students as learning objects that act as passive recipients of information, but as subjects who play an active role in each learning process by exploring their experiences alone. This is in line with the constructivist perspective which views that knowledge cannot be simply transferred from one person to another, but must be interpreted by each individual. Therefore, learning must be emphasized on the activities of students to build their own knowledge and be able to relate it to their real life everyday.

As a designer and implementer in learning, the selection of approaches, strategies, methods, and learning techniques which are an integral part of the learning process is a top priority for teachers. The approach applied will determine the strategies, methods and techniques to be used. The approach to be applied should be a student-centered approach (studentscentered approach) not teacher-centered approach (teacher-centered approach). A studentcentered approach requires teachers to develop learning that allows students to be actively involved in understanding such a complex world.

According to Law Number 20 of 2003 concerning the National Education System and Regulation of the Minister of National Education Number 22 of 2006 concerning content standards, broadly speaking Indonesian language learning in elementary schools is directed at improving students' skills to communicate in Indonesian properly and correctly both orally and in writing, as well as fostering an appreciation of the works of Indonesian human literature.

In fact, learning Indonesian in elementary schools has not been directed at developing communication skills, because more language is learned as a science, not as a means of communication. Students memorized the steps for making a speech, but they were confused when they were asked to speak in public. Likewise, students memorized how to write essays, but when they had to write they were confused about where to start. Symptoms of this kind are common symptoms of the results of our educational process. Education in schools overcrowded students' brains with various teaching materials that must be memorized.

Our educational process has never been directed to form intelligent human beings, have the skills to solve life's problems, and is not directed to form creative and innovative human beings. One of the reasons is the limited knowledge of teachers about various innovative learning approaches. The implication is that in learning, teachers are often confused when teaching Indonesian material. Even some teachers often complain about how difficult it is to teach Indonesian material, especially writing. And finally what happens in learning the teacher decides to use the same approach every day. This phenomenon ultimately has an impact on student learning outcomes which are still low, and can also be seen in the acquisition of the results of the national exam for Indonesian subjects which still have not met the achievement target.

Language learning that should be fun turns out to be far from expectations. Language which was originally an easy and exciting thing turned into a difficult thing (Goodman, 1986 in Puji Santosa 2010:22). This is because language is taught separately in schools. Reading is taught at a different time from writing. With a teaching system like this, students do not get the four complete language skills as they did before entering the world of education. The material taught is often not relevant to the real life of everyday students, so they are less motivated to learn the language (Puji Santosa, 2010). 
To improve language teaching, several countries, such as England, Australia, New Zealand, Canada, and the United States, have started to apply the whole language approach in the 80s (Routman, 1991, in Puji Santosa). However, in Indonesia the concept of a whole language learning approach in language learning in elementary schools is still very minimal.

Whole language approach is a language learning approach that presents language learning as a whole, not in isolation (Edelsky, 199; Froese, 1990; Goodman, 1986; Weaver, 1992, in Puji Santosa). Whole language experts believe that language is a whole that cannot be separated (Rigg, 1991, in Puji santosa, 2010). Therefore the teaching of the four language skills consisting of listening, speaking, reading and writing is presented at the same time, and language components such as grammar and vocabulary are presented in a complete, integrated, meaningful and real or authentic situation.

The whole language approach is based on constructivism which states that students form their own knowledge through their active role in whole and integrated learning (Roberts, 1996 in Puji Santosa). Whole language is a way to unify views about language, about learning and about the people involved in learning.

According to Routman (1991) and Froese (1991) the components of a whole language are reading aloud, journal writing, sustained silent reading, shared reading, guided reading, guided writing, independent reading, independent writing. These components provide opportunities for students to get the four language skills as a whole integrated in real or authentic situations. And this has been proven through a study conducted by Anderson et al (1988), independent reading given 10 minutes a day can improve reading skills.

Language learning should not be interpreted as teaching to understand and use language, but must be understood as inviting students to practice understanding and using language in everyday life. For this reason, in designing Indonesian language learning in elementary schools, teachers should pay close attention to the functions of the four main aspects of language skills. Because through these four aspects of language skills, a person can absorb various information, convey the results of his thoughts, ideas, reasoning to others freely without the burden of instructions. The four aspects of language skills are an inseparable unit. These language skills must be acquired in an authentic, holistic, and purposeful manner.

Based on the explanation above, it can be assumed that the writing skills and motivation of students to excel in learning Indonesian by applying the whole language learning approach will be different from the writing skills and motivation of students to excel in learning using conventional learning approaches.

This can be seen from the differences in the characteristics or characteristics of the two learning approaches. However, how far does the whole language learning approach affect students' writing skills and motivation to excel, especially fourth grade students? SDN 2 Sigli, has not been disclosed. Therefore, the researcher wants to study this problem further through a study entitled "Implementation of the Whole Language Approach". As the Development of Children's Language Learning Model". 


\section{Research Methods}

The subjects in this study were 10 students of SDN 2 Sigli consisting of 5 sons and 5 daughters. The research method used is the action research method or classroom action research (CAR), namely the form of self-reflective inquiry undertaken by particypants (teacher, student or principals, for example) in social (including educational) situations in order to improve the rationality and justice of (a) their own social or educational practices, (b) their understanding of these practices are carried out (Mulyasa, 2009:15).

The action intervention design used in this study is the spiral model of Kemmis and Taggart. The design of each cycle consists of planning activities, methods that will be used in action (planning), observations made by researchers and collaborators on action activities and children's abilities (observing), and reflection (reflection). Research starts from the planning stage then takes action and observations. Self-reflection is the basis for problem solving strategies and the basis for planning further actions in the next cycle.

This research is said to be successful if there is an increase in the percentage of at least 20\% as recommended by Mills (Mills, 2003:101). The data collection used in this action research is non-test, namely using observation.

The stages in filling out the observation sheet, the observer provides checklist data (V) on the adjusted initial reading ability appearance scale. The model used is a Likert scale model. This model is used to assess the attitude or behavior desired by researchers in addition to measuring a person's attitude towards certain objects. Each indicator item is marked with a checklist $(V)$ in the consistent column $(\mathrm{K})$, developing $(\mathrm{B})$, starting to appear $(\mathrm{MM})$, and not yet appearing (BM). Each indicator item is given a score of 1-4 according to the level of the answer.

Table 1. The Scale of Occurrence of Early Reading Skills

\begin{tabular}{|l|c|}
\hline Answer Options & Score \\
\hline Consistent & 4 \\
\hline Develop & 3 \\
\hline Start Appearing & 2 \\
\hline Hasn't Appeared & 1 \\
\hline
\end{tabular}

The assessment given has several provisions that have been mutually agreed upon between the researcher and the collaborator, namely:

Table 2. Criteria for the Intensity of the Occurrence Scale

\begin{tabular}{|l|l|}
\hline Scale & \multicolumn{1}{|c|}{ Score } \\
\hline Consistent & $\begin{array}{l}\text { The task is carried out by the child correctly, correctly, smoothly and } \\
\text { completely without assistance }\end{array}$ \\
\hline Develop & $\begin{array}{l}\text { The task is carried out by the child correctly, and complete without } \\
\text { assistance }\end{array}$ \\
\hline Start Appearing & $\begin{array}{l}\text { The task is done by the child correctly even though it is incomplete } \\
\text { and with assistance }\end{array}$ \\
\hline Hasn't Appeared & The task is done by the child wrong even with help \\
\hline
\end{tabular}

Beginning reading is a child's basic language skills related to the process of translating written symbols or letters and pictures into spoken words, the process consisting of visual and perceptual sensory. Whole language is a natural method of learning language skills in children, 
emphasizing a learning environment rich in language and writing, active and interactive learning, student-centered in order to develop writing, reading, speaking and listening skills.

According to Syakur (2020) reading is the process of a person in understanding a meaning in the text according to the level of ability possessed. Beginning reading is a score obtained from observations of reading skills related to the process of translating written symbols or letters and images into spoken words, the process consisting of visual and perceptual sensory. Whole language is data obtained from observations of language skills learning methods in children that emphasize a learning environment rich in language and writing, active and interactive learning, student-centered in order to develop writing, reading, speaking, and listening skills. Beginning reading is a very unique skill and plays an important role in the development of knowledge, and as a means of communication for human life (Gultom, 2021). Language validation of the product is carried out to find out the opinions of linguists about the straightforwardness of language, communicative, interactive, conformity to the development of students, conformity to language aspects, and the accuracy of the use of terms, and symbols in teaching materials (Arif, 2021).

The research instrument used was in the form of an observation guide for reading skills and a whole language learning guide. Early childhood education is a basic and strategic for human beings (Handayani, 2020). In line with the development of the education world in Indonesia, the competition level of education is very strict and need to be improvement especially in early childhood education (Simatupang, 2019). The initial reading ability instrument to determine the extent to which students' initial reading ability is by observing the child's initial reading ability during the game process takes place. The whole language learning guide instrument is used as a reference or learning guide in providing action during the research process.

Table 3. Grid \& Distribution of Items for Early Reading Ability Instruments

\begin{tabular}{|c|c|c|c|c|}
\hline Variable & Aspect & Indicator & $\begin{array}{c}\text { Deploymen } \\
\text { t Points }\end{array}$ & $\begin{array}{l}\text { Amoun } \\
\mathbf{t}\end{array}$ \\
\hline $\begin{array}{l}\text { Read } \\
\text { Beginning }\end{array}$ & $\begin{array}{l}\text { Decoding (Marking } \\
\text { letters or words) } \\
\text { Analogy (Aligning } \\
\text { letter or word } \\
\text { symbols) } \\
\text { Prediction } \\
\text { (Interpreting letters } \\
\text { or words) }\end{array}$ & $\begin{array}{l}\text { Know the graphic symbols } \\
\text { (letters or words) Say yes } \\
\text { Connecting simple writing with } \\
\text { symbols that represent it Make } \\
\text { simple writing through symbols } \\
\text { that represent it from the initial } \\
\text { letters that have been } \\
\text { determined } \\
\text { Form simple words and } \\
\text { syllables Mention words that } \\
\text { have the same syllable }\end{array}$ & $\begin{array}{l}4 \\
1,3 \\
2,6 \\
5,7 \\
8,9 \\
10\end{array}$ & $\begin{array}{l}2 \\
2 \\
2 \\
2 \\
1\end{array}$ \\
\hline
\end{tabular}

Table 4. Guidelines for Early Language Learning Whole Language Approach

\begin{tabular}{|l|l|l|}
\hline \multicolumn{1}{|c|}{ ASPECT } & \multicolumn{1}{|c|}{ INDICATOR } & \multicolumn{1}{c|}{ ACTIVITY } \\
\hline Approach & $\begin{array}{l}\text { Immersion (provides a script- } \\
\text { Learning } \\
\text { Whole } \\
\text { Language }\end{array}$ & $\begin{array}{l}\text { 1. Provide class library } \\
\text { rich environment) }\end{array}$ \\
$\begin{array}{l}\text { Provide various reading resources } \\
\text { (picture story books, alphabet books, } \\
\text { children's magazines, newspapers) in the } \\
\text { reading corner/library }\end{array}$ \\
\hline
\end{tabular}




\begin{tabular}{|c|c|}
\hline & $\begin{array}{l}\text { 3. Label all objects in class } \\
\text { 4. Create a bulletin board } \\
\text { 5. Hanging letters, alphabet } \\
\text { 6. Paste pictures of objects/animals from } \\
\text { the letter az }\end{array}$ \\
\hline $\begin{array}{l}\text { Demonstration (children learn } \\
\text { through models) }\end{array}$ & $\begin{array}{l}\text { 1. The teacher reads a story book to the } \\
\text { children. } \\
\text { 2. Children listen to children's stories from } \\
\text { cassettes } \\
\text { 3. Children watching VCDs containing } \\
\text { children's stories } \\
\text { 4. The teacher shows and shows pictures } \\
\text { and their writings } \\
\text { 5. Children retell the story and write down } \\
\text { the characters in the story } \\
\text { 6. The teacher shows, mentions, writes the } \\
\text { initial letters in a word, the child says as } \\
\text { many words as the initial letters written } \\
\text { by the teacher }\end{array}$ \\
\hline $\begin{array}{lcc}\text { Expectations (children } & \text { learn } \\
\text { according to } & \text { their } \\
\text { developmental stage) } & \end{array}$ & $\begin{array}{l}\text { 1. Design a fun study room (full of } \\
\text { pictures and colors, and simple writing) } \\
\text { 2. Provide educational game tools that } \\
\text { stimulate children to learn while playing, } \\
\text { such as picture cards, blocks, plasticine, } \\
\text { lego, hand puppets and sandboxes. } \\
\text { 3. Provide story books according to the } \\
\text { child's age (pictured and colored not too } \\
\text { thick) } \\
\text { 4. Providing VCD cassettes with themes } \\
\text { that are close to children such as the } \\
\text { animal world, me and my family, my } \\
\text { favorite food } \\
\text { 5. Facilitating children to learn according } \\
\text { to their developmental stage or ability, } \\
\text { not forcing children and not putting } \\
\text { pressure on children during the teaching } \\
\text { and learning process }\end{array}$ \\
\hline $\begin{array}{l}\text { Responsibility (children share } \\
\text { experiences as well as } \\
\text { responsibility for their own } \\
\text { learning process) }\end{array}$ & $\begin{array}{l}\text { 1. The child makes a list of words or a } \\
\text { collection of words in his alphabet book } \\
\text { 2. Stimulates children to express their } \\
\text { ideas or opinions at any time when } \\
\text { there is a problem or a certain theme } \\
\text { 3. Provide opportunities for each child to } \\
\text { share experiences with their friends, by } \\
\text { telling stories, demonstrations/simple } \\
\text { experiments } \\
\text { 4. After learning or using media (playing } \\
\text { tools) children are trained and guided to } \\
\text { tidy up again or put toys or books back } \\
\text { in their place. }\end{array}$ \\
\hline
\end{tabular}




\begin{tabular}{|c|c|}
\hline & $\begin{array}{l}\text { 5. The child demonstrates what he wrote } \\
\text { and pastes it on the bulletin board } \\
\text { 6. The child reads the storybook according } \\
\text { to his choice and puts it back on the } \\
\text { bookshelf }\end{array}$ \\
\hline $\begin{array}{l}\text { Employment (children are } \\
\text { actively involved in real and } \\
\text { purposeful learning and work) }\end{array}$ & $\begin{array}{l}\text { 1. Teachers involve all children in the } \\
\text { learning process } \\
\text { 2. Planning group work activities and } \\
\text { activities designed to involve children's } \\
\text { physical, emotional, and mind } \\
\text { 3. Children write and retell stories they like } \\
\text { 4. Children tell stories in their own } \\
\text { language, with their own expressions } \\
\text { and body movements. Teacher guides } \\
\text { and directs } \\
\text { 5. The teacher and children do } \\
\text { demonstrations and simple experiments, } \\
\text { then the children tell, describe, and } \\
\text { write them }\end{array}$ \\
\hline $\begin{array}{l}\text { Approximation (children are } \\
\text { stimulated and given the } \\
\text { opportunity to experiment) }\end{array}$ & $\begin{array}{l}\text { 1. Motivate children to read their own } \\
\text { story books and tell their contents } \\
\text { 2. Stimulate children to experiment with } \\
\text { writing and writing on the bulletin } \\
\text { board } \\
\text { 3. Stimulates students' courage, confidence } \\
\text { in giving answers and responding to } \\
\text { teachers } \\
\text { 4. Creating a classroom environment that } \\
\text { stimulates children's curiosity } \\
\text { 5. Child playing letter cards, word cards } \\
\text { and writing (matching pictures and } \\
\text { writing) }\end{array}$ \\
\hline $\begin{array}{l}\text { Feedback (children receive a } \\
\text { positive response from the } \\
\text { teacher) }\end{array}$ & $\begin{array}{l}\text { 1. Teachers and children give positive } \\
\text { responses with their courage to tell } \\
\text { stories or write words } \\
\text { 2. Discuss/hold small meetings with } \\
\text { children } \\
\text { 3. Read the biographies of the author of } \\
\text { the storybook that the child likes and } \\
\text { give praise or applause for the author } \\
\text { 4. Children are trained to give comments } \\
\text { or opinions about the story books they } \\
\text { read or the author } \\
\text { 5. Teachers minimize negative responses } \\
\text { to children } \\
\text { 6. Children are trained to take care of } \\
\text { story books to avoid damage }\end{array}$ \\
\hline
\end{tabular}


Quantitative data analysis used in this study is descriptive statistical analysis, (Arikunto, 2010:282), which is looking for the percentage and average value of increasing children's early reading ability and describing the percentage of data from the calculation of early reading ability of researchers and two collaborators in each cycle. As for the qualitative analysis, the researcher summarizes, analyzes, and interprets the results of field findings in the form of field notes, the results of calculating the initial reading ability and is supported by documentation, namely photos of activities. The percentage in this study was calculated to see the difference in reading ability before and after the action was given.

\section{Discussion}

After carrying out various activities in the first cycle, the results of the initial reading ability observation were obtained. The results of these observations were then analyzed to test the action hypothesis to see the effect of giving actions in the form of whole language learning on language skills, especially early reading skills.

Testing the action hypothesis using the calculation of the percentage of ability and the percentage increase in the first cycle. Based on the data analysis using the percentage, it was found that there was an increase in the initial reading ability after the action was taken in the first cycle compared to the pre-research percentage.

The percentage of the child's early reading ability after the action in the cycle is $85.50 \%$. The percentage of children's early reading ability based on the results of pre-research observations is $30.25 \%$, so it can be concluded that the percentage increase in achieving the desired results exceeds the percentage of success, which is at least $20 \%$. The percentage increase from pre-research to cycle I was $55.25 \%$, as shown in Table 5 below.

Based on the data in table 5 , it can be seen that the initial reading ability of children after being given the action has increased significantly from the results of pre-research observations, even reaching more than $50 \%$. This happens because the initial reading learning in group $\mathrm{B}$ is carried out by paying attention to the principles of whole language learning.

Table 5. Results of Pre-Research Data Analysis and Cycle I

\begin{tabular}{|l|l|l|l|l|l|}
\hline Respondent & \multicolumn{2}{|c|}{ Pre Cycle } & \multicolumn{2}{c|}{ Cycle Results } & Enhancement \\
\hline A & 12 & 30.00 & 32 & 80.00 & 50.00 \\
\hline B & 12 & 30.00 & 35 & 87.50 & 57.50 \\
\hline C & 11 & 27.50 & 30 & 75.00 & 47.50 \\
\hline D & 11 & 27.50 & 34 & 85.00 & 57.50 \\
\hline E & 11 & 27.50 & 34 & 85.00 & 57.50 \\
\hline F & 16 & 40.00 & 39 & 97.50 & 57.50 \\
\hline G & 10 & 25.00 & 33 & 82.00 & 57.50 \\
\hline H & 16 & 40.00 & 39 & 97.50 & 57.50 \\
\hline I & 11 & 27.50 & 31 & 77.50 & 57.50 \\
\hline J & 11 & 27.50 & 35 & 87.50 & 60.00 \\
\hline Amount & $\mathbf{1 2 1}$ & $\mathbf{3 0 2 . 5 0}$ & $\mathbf{3 4 2}$ & $\mathbf{8 5 5 . 0 0}$ & $\mathbf{5 5 2 . 5 0}$ \\
\hline Average & $\mathbf{1 2 . 1}$ & $\mathbf{3 0 . 2 5 \%}$ & $\mathbf{3 4 . 2}$ & $\mathbf{8 5 . 5 0 \%}$ & $\mathbf{5 5 . 2 5 \%}$ \\
\hline
\end{tabular}

Learning to read early before taking action using a scholastic learning method, where children are faced with a school atmosphere full of tension, children's daily activities are working on worksheets in the form of magazines and textbooks that are repeated so that it is boring and 
not fun children rarely do not want to do assignments because they feel unable. Learning activities tend to be teacher-centered so that this kind of learning process is not meaningful for children, even learning only focuses on developing reading, writing, and arithmetic skills. The other abilities were barely even stimulated.

Graphic symbol activities (letters or words) do not use letter cards or word cards, but the teacher writes a few words on the blackboard and then the children are led to spell and read the word. The teacher asks the children one by one to come forward to read the word after the teacher gives the task to the child to copy the word written on the blackboard in the child's notebook. Activities like this are done every day for children so that sometimes many children complain, and don't want to complete assignments because they can't. For word or writing recognition activities, it is usually done by means of children working on worksheets in textbooks or magazines. On the available worksheets or words with dots, the child's task is to thicken the dots in the available columns and then imitate the letters and words in the next row with a total of 5-6 rows. In addition, children are taught to write conjunctive letters.

The situation in the classroom is very different from when the researcher and two collaborators carry out learning activities using a whole language approach. The classroom environment is set full of reading and written materials, labels objects in the classroom and provides a reading area filled with children's story books. This is in accordance with the principle of immersion. Every day children are in an environment that stimulates children to read, even every morning before starting learning activities the children are invited to walk to see, observe and read every word attached to objects in the classroom to link children between concepts and the symbols that represent them.

The principle of demonstration, the teacher is a good example for children, both in terms of the language used daily to children and other teachers. Giving an example in reading, learning activities always start by reading a story book that the child has chosen and invites the child to read a book in the reading area. Stimulate children to tell stories and express opinions and respect children when children express their opinions by listening to children's complaints or opinions. Previously, the activity did not start with reading a book, the children did not dare to express their opinion because of shame and fear.

\subsection{Expectations}

Learning activities are presented in a pleasant atmosphere for children, there is no coercion and pressure on children and children learn by using the principles of early childhood learning while playing and playing while learning. Letter and word recognition activities are carried out using media that are attractive to children, namely letter cards, word cards and picture cards. Introduce letters and words by playing guessing card letters, matching letters to pictures, connecting words to pictures. Previously, the only media used were worksheets in the form of magazines and package books so that children felt bored.

\subsection{Responsibility}

Children are invited to read their own favorite books in the reading area during breaks and free play time. Furthermore, children are invited to tidy up the books and play equipment that have been used in their place with the aim of training a sense of responsibility. Children make word lists by searching and cutting out words that start with the same in shopping catalogs and food packaging. Previously there was no opportunity to read story books because they were not available in the classroom and the play equipment that children used. Usually the teacher cleans it up after the children go home, so there is no sense of responsibility for the child. 


\subsection{Employment}

The teacher always involves children in every activity from the beginning to the end of the activity. In the activity of labeling objects in the classroom, children are fully involved by sticking words to objects and of course with the guidance of the teacher. Even when the teacher prepares the learning media that will be used, the children are invited to prepare it. This is different from the previous situation where all the media that will be used, the teacher prepares and stores them so that the children just sit back and follow the teacher's instructions.

\subsection{Approximation}

Providing stimulation for experimenting activities in combining letters into syllables, combining syllables into words, and making writing and trying to read books on their own so that it creates a sense of confidence in children. Previously, activities that children usually did on worksheets were coloring, writing, and counting, so that children did not explore less.

\subsection{Feedback}

The teacher always gives a positive response and reward to the child when the child asks questions, expresses his opinion and when the child successfully completes the task or is able to answer the teacher's questions so as to motivate the child to continue learning.

Based on the results of quantitative data analysis by calculating the percentage increase in initial reading ability, it is known that the results of the initial reading ability observation after the action in the first cycle has increased. Data from pre-research observations showed that the maximum score obtained by the child was 16 with a percentage of $40 \%$ and the minimum score obtained by the child was 10 with a percentage of $25 \%$.

The final result of calculating the average percentage of 10 children is $30.25 \%$. Data from observations in the first cycle showed that the maximum score was 39 with a percentage of $97.50 \%$ and the minimum score obtained by children was 30 with a percentage of $70 \%$. The final result of the calculation is an average of $85.50 \%$. Based on these data, it is known that the percentage of early reading ability in the first cycle is greater than the percentage increase of $55.25 \%$. These results indicate conformity with the action.

The results of the qualitative analysis prove that the provision of action in the form of a whole language learning approach by emphasizing the principles of meaningful and comprehensive learning, providing an environment rich in literature or reading materials can help improve children's early reading skills, both in terms of the ability to recognize writing, read words with letter sounds the truth, as well as reading story books. With real storytelling, playing, reading and writing activities, immersing children in an environment rich in writing and comprehensive learning, so that reading skills can be improved.

The ability to interpret letter or word symbols (decoding) or interpret symbols with letter and word symbol recognition activities, children look enthusiastic and follow the activity to completion. Letter and word recognition activities using letter cards, word cards, and picture cards. Recognition of letters through singing, playing guessing letters, finding and observing letters on the walls and reading story books about letters. The letter recognition activity begins by introducing vowels by connecting them with objects in the classroom and pictures of fruits according to the plant theme. Word recognition is carried out by searching for words in shopping catalogs and food packaging as well as reading a few simple words in story books with the correct pronunciation of sounds. 
The ability to align letter or word symbols (analogy) involves connecting words with appropriate images, matching letters with images or words, looking for images with the same initial letter and looking for as many words as possible with the same beginning. All children were actively involved in all these activities. The use of interesting and varied media supports activities and children's interest in participating in activities is also very high, it is proven that children look happy and enthusiastic in participating in activities. This can be seen when children are assigned to carry objects ranging from dice, duku, wallets, leaves, branches, lunkhead, donuts, etc., out of 20 children only 4 children did not match the objects, namely some brought apples, oranges, grapes, and guavas.

The activity of interpreting letter or word symbols (prediction) is carried out by combining letters into syllables, combining syllables into words, making words from syllables, looking for as many words as possible starting with the same syllable and reading words not only pictures. The teacher guides children in combining letters into syllables and combining syllables into meaningful words. All children are given the opportunity to try themselves by using letter cards, syllable cards and picture cards. This activity was followed by the children enthusiastically, all the children scrambled to try and this activity was repeated until the children understood.

Thus the principles of whole language learning, namely immersion, responsibility, demonstration, expectation, employment, approximation, and feedback, if developed and deepened, can be used as a reference in designing language learning activities, especially reading skills learning.

Based on the application of whole language principles, learning activities are carried out with activities that are fun for children and do not forget the principles of early childhood learning. The activity of reading story books repeatedly will increase children's knowledge of letter symbols, even though the early stages of children only read pictures. However, as the picture is accompanied by experience and stimulation, children will begin to develop understanding and will realize that what is being read is written. The activity of matching letters with pictures or matching words with pictures will add to the child's experience of the concept of the relationship between symbols and sounds.

Beginning reading is a stage in the process of learning to read for children. Children learn to acquire the ability and master reading techniques and capture the content of reading well. Language learning aims to improve students' ability to communicate effectively, both orally and in writing. The ability to read as one of the resistive written language skills needs to be possessed in order to be able to communicate in writing. The implementation of preliminary reading can be done in two stages. First, the reading period without books and the period using media or visual aids such as letter cards, word cards, picture cards or objects that start with the same letter. Second, learning by using books is a reading activity using books as lesson materials.

\section{Conclusion}

Based on the results of the study, researchers can conclude that the implementation of the whole language approach model can actually improve early childhood reading skills. This is evident from the significant increase in each cycle through the application of the whole language approach with the stages of class action starting from activity planning, implementation, and observation to reflection. 
Based on observations in the pre-cycle (pre-study) where at first the percentage of children's early reading ability was still $30.25 \%$. In the first cycle, after the action was carried out for 7 meetings, the percentage increased to $85.50 \%$. Based on these data, it shows an increase in the percentage of early reading skills from the results of pre-cycle observations of $55.25 \%$.

\section{References}

Anderson, RC, et al. (1985). Becoming a nation of readers, the report of the commission of reading. Washington: The National Institute of Education.

Arif, S., et.al. (2021). The Development of Indonesian Language Teaching Materials for Class VII Semester 1 Based on North Sumatran Local Wisdom and the Digitization of Learning. Budapest International Research and Critics in Linguistics and Education (BirLE) Journal Vol 4 (4): 1158-1168.

Arikunto, S. (2006). Classroom action research. Jakarta: Earth Literacy.

Dhelo, S. and Eisele, B. (2001). Managing the whole language classroom, a complete teaching resource guide. Creative Teaching Press, Cypress.

Goodman, K. (2006). What's whole in whole language? Richmond Hill. Ontario: Heinemann, Portsmouth.

Gultom, O., Yus, A., and Sriadhi. (2021). Development of Interactive Learning Multimedia Reading Early Children's Beginning. Budapest International Research and Critics in Linguistics and Education (BirLE) Journal Vol 4 (1): 24-34.

Hairuddin, et al. (2007). Indonesian Language Learning. Jakarta: Directorate General of Higher Education Ministry of National Education.

Handayani, S., et al. (2020). The Effectiveness of Early Childhood Inclusive Education Textbook for Students of Inclusive Education Classes in UNIMED. Budapest International Research and Critics in Linguistics and Education (BirLE) Journal Vol 3 (1): 71-79.

Mills, GE (2003). Action research: guide for the teacher researcher. New Jersey: Second Edition Pearson Education.

Ministry of Education. (2009). Generic learning menu for early childhood. Jakarta: Ministry of National Education.

Mulyasa, E. (2009). Becoming a professional teacher creates creative and fun learning. Bandung: Rosada Karya Youth.

Morrow, LM (1993). Literacy development in the early years, helping children read and write. Boston: Allyn and Bacon.

Simatupang, D., Sembiring, and S.W.S. (2019). The Effect of Numbered Heads Together Learning Model Towards Social Emotional Ability of Children 5-6 Years Old in Assisi Kindergarten Medan. Budapest International Research and Critics in Linguistics and Education (BirLE) Journal Vol 2 (4): 533-538.

Syakur, A., Fanani, Z., and Ahmadi, R. (2020). The Effectiveness of Reading English Learning Process Based on Blended Learning through "Absyak" Website Media in Higher Education. Budapest International Research and Critics in Linguistics and Education (BirLE) Journal Vol 3 (2): 763-772.

Weaver, C. (2003). Understanding whole language, from principles to practice. Michigan: Irwin Publishing.

Woolfolk, A. (2009). Educational psychology, edition $\mathrm{x}$ active learning edition. New York: Prentice Hall.

Yarmi, G. (2008). Approaches and strategies for learning Indonesian language and literature in elementary schools. Sower Education Journal No.11/7th Year/Dec 2008.

Yeager, DC (1999). The Whole Language Companion, A Guide to Planning Personalizing and Implementing The Whole Language Classroom. Illinois: Scott Forestman and Company. 